\title{
Terapi Aktivitas Kelompok Stimulasi Persepsi Pada Pasien Risiko Perilaku Kekerasan
}

\section{Meri Natalia Simare Mare ${ }^{1}$, Dirman Laia², Hikmah Sukitiro ${ }^{3}$, Fanny Fadillah ${ }^{4}$, Icca Cerahwati ${ }^{5}$, Reynhad Daniel Manurung ${ }^{6}$}

$\underline{\text { Merrysimaremare122@gmail.com }}$

\begin{abstract}
Abstrak
Pasien skizoprenia sering dikaitkan dengan perilaku kekerasan yang dapat membahayakan diri sendiri maupun orang lain ataupun berisiko juga dengan lingkungan sekitarnya, baik secara fisik, emosional, seksual, dan verbal. Risiko perilaku kekerasan merupakan gejala dari pasien skizofrenia yang dapat dikontrol melalui terapi Aktivitas Kelompok.Terapi kelompok merupakan suatu psikoterapi yang dilakukan sekelompok pasien bersama-sama dengan berdiskusi satu sama lain yang dipimpin atau arahkan oleh perawat spesialis jiwa atau perawat jiwa yang telah terlatih. Dalam pelaksanaan TAK jumlah Pasien terdiri dari 6 orang, dimana pesertanya 2 Laki-laki dan 4 Perempuan. Hasil dari kegiatan TAK Pasien mampu memperagakan/ mengekspresikan SP Risiko Perilaku Kekerasan, dan mampu mengamati dengan baik jalan nya kegiatan TAK. Setelah mendapatkan terapi aktivitas kelompok stimulasi persepsi, pasien di Yayasan pemenang jiwa sumatera terjadi peningkatan pengetahuan, pemahaman tentang cara mengontrol emosi
\end{abstract}




\section{BAB 1 \\ PENDAHULUAN}

\subsection{Latar Belakang}

Skizofrenia merupakan sekumpulan sindroma klinik yang ditandai dengan perubahan kognitif, emosi, persepsi dan aspek lain dari perilaku. Skizofrenia merupakan suatu kondisi gangguan psikotik yang ditandai dengan gangguan utama dalam pikiran, emosi dan perilaku yang terganggu, dimana berbagai pemikiran tidak saling berhubungan secara logis, persepsi dan perhatian yang keliru (Makhruzah, Putri, \& Yanti, 2021). Prevalensi yang menderita skizofrenia atau psikosis sebesar $7 \%$ per 1000 dengan cakupan pengobatan 84, $9 \%$ dan gangguan prevalensi mental emosional yang di tunjukan pada usia 15 tahun keatas mencapai 9,8 \% dari jumlah penduduk (Riskesdas, 2018).

Skizofrenia merupakan gangguan jiwa yang dapat berakhir dengan hilanngya nyawa seseorang. Dalam penanganan penyakit ini karena jiwa yang tergangangu maka di butuhkan adalah terapi, rehabilitasi serta dengan konseling. Upaya terbesar untuk penangan penyakit gangguan jiwa terletak pada keluarga dan masyarakat, dalam hal ini terapi terbaik adalah bentuk dukungan keluarga dalam mencegah kambuhnya penyakit skizofrenia (Pitayanti, \& Hartono, 2020).

Skizofrenia menimbulkan distorsi pikiran, distorsi persepsi, emosi, dan tingkah laku sehingga pasien dengan skizofrenia memiliki Risiko lebih tinggi berperilaku agresif dimana perubahan perilaku secara dramatis terjadi dalam beberapa hari atau minggu. Pasien skizoprenia sering dikaitkan dengan perilaku kekerasan yang dapat membahayakan diri sendiri maupun orang lain ataupun berisiko juga dengan lingkungan sekitarnya, baik secara fisik, emosional, seksual, dan verbal. Berdasarkan data tahun 2017 dengan Risiko perilaku kekerasan sekitar $0,8 \%$ atau dari 10.000 orang menunjukkan Risiko perilaku kekerasan sanggatlah tinggi (Pardede, Siregar \& Hulu, 2020). 
Faktor psikologis yang dapat menyebabkan pasien mengalami Risiko prilaku kekerasan yaitu : Kepribadian yang tertutup, kehilangan, aniaya seksual, kekerasan dalam keluarga. Pada aspek fisik tekanan darah meningkat, denyut nadi dan pernapasan meningkat, mudah tersinggung, marah, amuk serta dapat mencederai diri sendiri maupun orang lain. Adapun dampak yang ditimbulkan oleh pasien yang mengalami perilaku kekerasan yaitu kehilangan kontrol akan dirinya, dimana pasien akan dikuasi oleh rasa amarahnya sehingga pasien dapat melukai diri sendiri, orang lain dan lingkungan, bila tidak ditangani dengan baik maka perilaku kekerasan dapat mengakibatkan kehilangan kontrol, risiko kekerasan terhadap diri sendiri, orang lain serta lingkungan (Sepalanita \& Khairani, 2019)

Risiko perilaku kekerasan merupakan gejala dari pasien skizofrenia yang dapat dikontrol melalui terapi Aktivitas Kelompok.Terapi kelompok merupakan suatu psikoterapi yang dilakukan sekelompok pasien bersamasama dengan berdiskusi satu sama lain yang dipimpin atau arahkan oleh perawat spesialis jiwa atau perawat jiwa yang telah terlatih. Terapi kelompok adalah terapi psikologi yang dilakukan secara kelompok untuk memberikan stimulasi bagi Pasien dengan gangguan interpersonal. Beberapa faktor yang dapat mempengaruhi terjadinya peningkatan kemampuan mengontrol perilaku kekerasan setelah dilakukan Terapi Aktivitas kelompok stimulasi persepsi adalah konsentrasi dan adanya ketertarikan responden terhadap Terapi Aktivitas Kelompok yang dilaksanakan, sehingga setelah dilaksanannya TAK ini, kemampuan pasien dalam mengontrol perilaku kekerasan dapat mengalami peningkatan (Pardede \& Laia., 2020).

Terapi modalitas yang tepat untuk mengatasi Risiko prilaku kekerasan yaitu terapi aktivitas kelompok stimulasi persepsi yang bertujuan untuk meningkatkan kemampuan sensori, untuk memusatkan perhatian, kesegaran jasmani dan mengespresikan perasaan.Terapi ini dilakukan menggunakan aktivitas sebagai stimulus dan terkait dengan pengalaman dalam kehidupan untuk mendiskusikan dalam kelompok. Dengan aktifitas kelompok ini, maka 
akan memberikan dampak positif dalam upaya pencegahan, meningkatkan pengobatan, dan pemulihan kesehatan (Pratiwi., 2020).

Berdasarkan survey yang dilakukan di Yayasan pemenang jiwa, didapatkan jumlah pasien sebesar 70 pasien, dimana pasien dengan diagnosa risiko perilaku kekerasan menjadi diagnosa paling lazim di yayasan pemenang jiwa, sehinggan kelompok tertarik mengangkat diagnosa risiko perilaku kekerasan untuk dijadikan terapi aktivitas kelompok sebagai stimulasi persepsi pasien.

\subsection{Tujuan}

\subsubsection{Tujuan Umum}

Setelah mengikuti kegiatan ini Pasien dapat lebih menerapkan stategi pelaksanaan Risiko Perilaku Kekerasan secara fisik dan sosial dalam mengontrol Risiko Perilaku Kekerasan.

\subsubsection{Tujuan Khusus}

1. Pasien dapat mengekspresikan perasaannya lewat cerita

2. Pasien dapat mengetahui cara mengendalikan Risiko Perilaku Kekerasan dengan SP

3. Pasien dapat melakukan aktivitas kognitif dengan mendengarkan, bersosialisasi, menebak ekspresi wajah, mempraktikkan SP Risiko Perilaku Kekerasan

4. Pasien dapat melakukan aktivitas motorik dengan bekerja sama dengan melatih kekompakan dalam kelompok.

5. Pasien dapat melatih konsentrasi melalui permainan. 


\section{BAB 2 \\ STANDAR PELAKSANAAN TERAPI AKTIFITAS KELOMPOK STIMULASI PERSEPSI}

\subsection{Metode Terapi aktifitas kelompok (TAK)}

Metode yang digunakan pada terapi aktifitas kelompok ini adalah metode:

2.1.1 Perkenalan diri pada seluruh perawat

2.1.2 Menanyakan perasaan Pasien pada saat terapi berjalan

\subsection{Waktu dan Tempat}

Hari/tanggal : $\quad 16$ Maret 2021

Jam : 10:00 WIB

Tempat $\quad$ : $\quad$ Yayasan Pemenang Jiwa

\subsection{Pasien dan Ruangan Pasien}

Pasien yang mengikuti kegiatan berjumlah 6 orang dari Yayasan pemenang jiwa terdiri dari:

1. Ny. Tiurma

2. Ny. Rebecca

3. Ny. Juli

4. Tn.Budi Harsono

5. Tn.Aseng

6. Tn. Acong

\subsection{Setting tempat}

1. Terapis dan Pasien duduk bersama dalam lingkaran

2. Ruangan yang nyaman dan tenang 


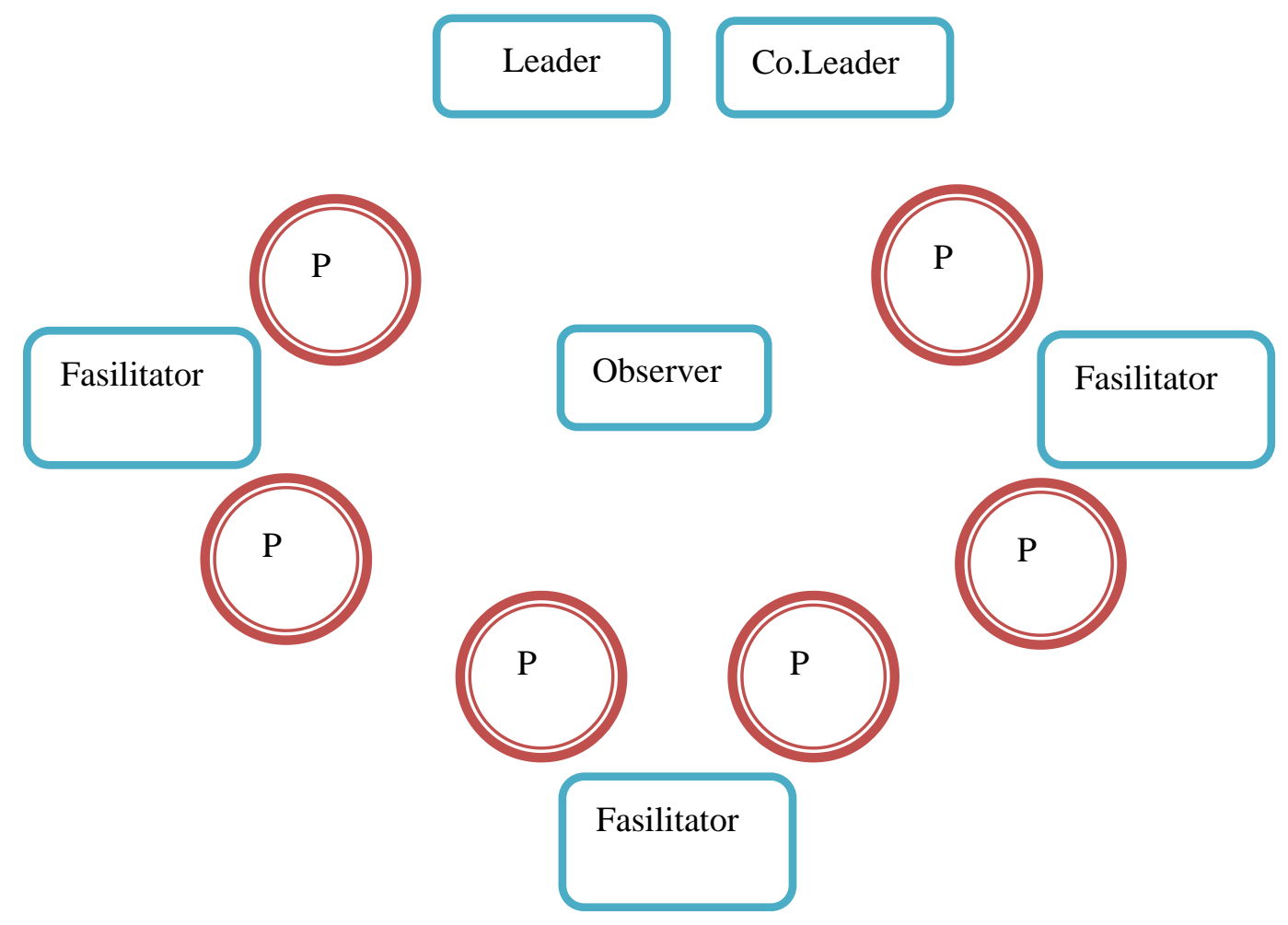

Keterangan Gambar:

L :Leader

CL :Co Leader

F :Fasilitator

O : Observer

\subsection{Media dan Alat}

1. Handphone

2. Speaker

3. Music/lagu

4. Buku catatan dan pulpen

5. Jadwal kegiatan pasien

6. Bola

7. Gambar ekpresi wajah emoji 


\subsection{Susunan Pelaksanaan}

Yang bertugas dalam TAK kali ini di sesuaikan dengan petugas setiap sesi yang telah disepakati sebagai berikut :

1. Leader : Meri Natalia Simare Mare

2. Co.Leader : Reynhard Daniel Manurung

3. Fasilitator 1 : Icca Cerahwati

4. Fasilitator 2 : Hikmah Sukitiro

5. Fasilitator 3 : Fanny Fadillah

6. Observer 2 : Dirman Laia

\subsection{Uraian Tugas Pelaksana}

\subsubsection{Leader :}

1. Menyampaikan tujuan dan peraturan kegiatan terapi aktivitas kelompok menyiapkan proposal kegiatan TAK

2. Mampu memotivasi anggota untuk aktif dalam kelompok dan memperkenalkan dirinya

3. Mampu memimpin terapi aktivitas kelompok dengan baik dan tertib Menetralisir bila ada masalah yang timbul dalam kelompok

\subsubsection{Co.Leader :}

1. Mendampingi Leader

2. Menjelaskan aturan permaian

3. Menyampaikan informasi dari fasilitator ke leader tentang aktivitas Pasien

4. Mengingatkan leader jika kegiatan menyimpang dari perencanaan yang telah di buat

5. Mengambil alih posisi leader jika leader mengalami blocking dalam proses terapi

\subsubsection{Fasilitator :}

1. Menyediakan fasilitas selama kegiatan berlangsung ikut serta dalam kegiatan kelompok 
2. Memfasilitasi dan memberikan stimulus dan motivator pada anggota kelompok untuk aktif mengikuti jalannya terapi

\subsubsection{Observer :}

1. Mengobservasi jalannya proses kegitan

2. Mengamati serta mencatat perilaku verbal dan non verbal pasien selama kegiatanberlangsung (dicatat pada format yang tersedia)

3. Mengawasi jalannya aktivitas kelompok dari mulai persiapan, proses , hingga penutupan

4. Memberikan hadiah (reward) bagi pasien yang menang dalam permainan.

\subsection{Kriteria Pasien}

1. Pasien dengan Risiko Perilaku Kekerasan yang sudah kooperatif

2. Pasien yang tidak mengalami gangguan komunikasi verbal

3. Pasien bisa tulis dan baca

4. Pasien yang bersedia mengikuti TAK

\subsection{Antisipasi masalah}

1. Sebelum kegiatan dilaksanakan, perawat memberi kesempatan kepada setiap peserta untuk BAB dan BAK

2. Fasilitator memotivasi peserta yang tidak berpartisipasi

3. Menjaga pintu keluar unuk mengantisipasi Pasien melarikan diri dari tempat kegiatan

\subsection{Langkah-langkah Kegiatan}

\subsubsection{Persiapan}

1. Membuat kontrak dengan anggota kelompok

2. Mempersiapkan alat dan tempat pertemuaan

\subsubsection{Orientasi}

1. Salam teraupetik 
Salam dari leader kepada Pasien. Leader/Co Leader memperkenalkan diri dan tim terapis lainnya.

2. Evaluasi/Vasilidasi

Leader menanyakan perasaan dan keadaan Pasien saat ini.

\section{Kontrak}

a. Menjelaskan tujuan kegiatan

b. Menjelaskan aturan main yaitu :

1) Berkenalan dengan anggota kelompok

2) Jika ada peserta yang akan meninggalkan kelompok, harus minta izin pada pemimpin TAK

3) Lama Kegiatan 45 menit

4) Setiap pasien mengikuti kegiatan dari awal sampai akhir

\subsubsection{Tahap Kerja}

1. Seluruh Pasien dibuat berbentuk lingkaran

2. Hidupkan music dan edarkan bola berlawanan dengan arah jarum jam

3. Pada saat tape dimatikan, anggota kelompok yang memegang bola, mendapat giliran untuk perkenalan dengan anggota kelompok yang ada di sebelah kanan dengan cara:
a. Memberi salam
b. Menyebutkan nama lengkap, nama panggilan, asal dan hobby.
c. Menanyakan nama lengkap, nama panggilan, asal dan hobby
d. Dimulai oleh terapis sebagai contoh.

4. Setelah memperkenalkan diri Pasien menebak ekspresi wajah dan mengambil gulungan kertas yang ada di mangkuk yang berisi SP Risiko Perilaku Kekerasan, kemudian pasien diharuskan memperagakan SP yang didapat

5. Ulangi musik kembali, dan Pasien kembali melempar bola, ketika musik berhenti, Pasien yang memegang bola, kembali memperagakan point $\mathrm{c}$ dan $\mathrm{d}$. 


\subsubsection{Tahap Terminasi}

1. Leader atau Co.Leader memberikan pujian atas keberhasilan dan kerjasama kelompok

2. Leader atau Co.Leader menanyakan perasaan Pasien setelah mengikuti kegiatan TAK

3. Fasilitator membagikan Snack

4. Leader atau Co.Leader menganjurkan Pasien untuk sering bersosialisasi, selalu bekerjasama, dan memasukkan kegiatan mengontrol Risiko Perilaku Kekerasan ke dalam kegiatan harian sebanyak $2 \times 1$.

5. Observer mengumumkan pemenang

6. Fasilitator membagikan hadiah kepada pemenang

\subsubsection{Evaluasi}

1. Pasien mengikuti kegiatan dari awal hingga akhir kegiatan

2. Kerja sama Pasien dalam kegiatan

3. Pasien merasa senang selama mengikuti kegiatan

\subsection{Tata tertib dan Antisipasi Masalah}

2.11.1 Tata tertib pelaksanaan TAK Risiko Perilaku Kekerasan

1. Peserta bersedia mengikuti kegiatan TAK Risiko Perilaku Kekerasan sampai dengan selesai

2. Peserta wajib hadir 5 menit sebelum acara TAK Risiko Perilaku Kekerasan dimulai

3. Peserta berpakaian rapi, bersih, dan sudah mandi

4. Peserta tidak diperkenankan makan, minum, merokok selama kegiatan TAK berlangsung

5. Jika ingin mengajukan/menjawab pertanyaan, peserta mengangkat tangan kanan dan berbicara setelah dipersilahkan oleh pemimpin

6. Peserta yang mengacaukan jalannya acara akan dikeluarkan dari permainan 
7. Peserta dilarang meninggalkan tempat sebelum acara TAK selesai

8. Apabila waktu yang ditentukan untuk melaksanakan TAK telah habis, sedangkan permainan belum selesai, maka pemimpin akan meminta persetujuan anggota untuk memperpanjang waktu TAK

2.11.2 Antisipasi kejadian yang tidak diinginkan pada proses TAK

1. Penanganan Pasien yang tidak efektif saat aktifitas kelompok

a. Memanggil Pasien

b. Memberi kesempatan kepada Pasien tersebut untuk menjawab sapaan perawat atau Pasienyang lain

2. Bila Pasien meninggalkan permainan tanpa pamit:

a. Panggil nama Pasien

b. Tanya alasan Pasien meninggalkan permainan

c. Berikan penjelasan tentang tujuan permainan dan berikan penjelasan pada Pasien bahwaPasien dapat melaksanakan keperluannya setelah itu Pasien boleh kembali lagi

3. Bila ada Pasien lain ingin ikut

a. Berikan penjelasan bahwa permainan ini ditujukan pada Pasien yang telah dipilih

b. Katakan pada Pasien lain bahwa ada permainan lain yang mungkin dapat diikuti oleh Pasien tersebut

c. Jika Pasien memaksa, beri kesempatan untuk masuk dengan tidak memberi peran pada permainan tersebut. 


\section{BAB 3}

EVALUASI

\subsection{Hasil Pelaksanaan Kegiatan TAK}

Kegiatan TAK dilaksanakan pada 16 Maret 2021 jam 10.00 WIB. Kegiatan dilakukan di dalam ruang tamu pemanang jiwa. Dalam pelaksanaan TAK, jumlah Pasien berjumlah 6 orang, peserta Laki-laki 2 orang dan perempuan 4 orang sesuai dengan proposal yang telah diajukan. Dalam terapi aktivitas kelompok perawat melakukan kontrak kepada pasien sehari sebelum TAK dilakukan. Mempersiapkan alat dan menyeting tempat dilakukan sebelum pasien datang di tempat pelaksanaan TAK. Suasana kegiatan TAK mulai dari awal hingga akhir acara berlangsung aman dan nyaman, Pasien sangat bersemangat. Pasien mampu memperagakan /mengekspresikan SP Risiko Perilaku Kekerasan, dan Pasien mampu mengamati dengan baik jalan nya kegiatan TAK.

Sebelum TAK dilaksanakan, leader memperkenalkan diri kepada pasien dan leader memberikan kesempatan untuk co-leader, fasilitator dan observer untuk memperkenalkan diri kepada pasien dan memberikan pasien kesempatan untuk memperkenalkan dirinya masing-masing. Leader dan coleader saling bergantian menjelaskan peraturan terapi aktivitas kelompok, seperti bagiamana peraturan yang di buat saat terapi aktivitas kelompok dilaksanakan, durasi berjalannya terapi aktivitas kelompok dan memberikan infromasi kepada pasien bahwa perawat yang berada disebelah pasien sebagai fasilitator untuk membantu pasien selama berjalannya terapi aktivitas kelompok.

Dalam terapi aktivitas kelompok, leader dan co-leader sudah melakukan tugasnya untuk menjelaskan jalannya terapi aktivitas kelompok dan memimpin jalannya terapi. Fasilitator sudah melakukan tugasnya untuk membantu pasien selama berjalannya terapi aktivitas kelompok. Observer telah melakukan tugasnya dengan mengamati jalannya terapi aktivitas kelompok apakah pasien mampu melakukan SP yang sudah ditentukan terapis. 


\subsubsection{Evaluasi Kemampuan Verbal}

\begin{tabular}{|l|l|c|c|c|c|}
\hline No & $\begin{array}{c}\text { Nama } \\
\text { Pasien }\end{array}$ & $\begin{array}{c}\text { Menanyakan } \\
\text { nama Pasien }\end{array}$ & $\begin{array}{c}\text { Menanyakan } \\
\text { nama panggilan }\end{array}$ & $\begin{array}{c}\text { Menanyakan } \\
\text { ruangan }\end{array}$ & $\begin{array}{c}\text { Menanyakan } \\
\text { hobby }\end{array}$ \\
\hline 1 & Tn. A & $\checkmark$ & $\checkmark$ & X & X \\
\hline 2 & Tn. A & $\checkmark$ & $\checkmark$ & $\checkmark$ & $\checkmark$ \\
\hline 3 & Ny. Y & $\checkmark$ & $\checkmark$ & $\checkmark$ & $\checkmark$ \\
\hline 4 & Ny. R & $\checkmark$ & $\checkmark$ & $\checkmark$ & $\checkmark$ \\
\hline 5 & Ny. M & $\checkmark$ & $\checkmark$ & $\checkmark$ & $\checkmark$ \\
\hline 6 & Ny. Y & $\checkmark$ & $\checkmark$ & $\checkmark$ & $\checkmark$ \\
\hline
\end{tabular}

\begin{tabular}{|c|c|c|c|c|c|c|c|}
\hline No & Aspek penilaian & Tn.A & Tn.A & $\begin{array}{c}\text { Ny. } \\
\text { Y }\end{array}$ & $\begin{array}{l}\text { Ny. } \\
\text { R }\end{array}$ & $\begin{array}{l}\mathrm{Ny} . \\
\mathrm{M}\end{array}$ & Ny.Y \\
\hline 1 & $\begin{array}{l}\text { Dapat mengikuti } \\
\text { kegiatan dengan } \\
\text { aktif dari awal } \\
\text { sampai akhir }\end{array}$ & $\checkmark$ & $\checkmark$ & $\checkmark$ & $\checkmark$ & $\checkmark$ & $\sqrt{ }$ \\
\hline 2 & $\begin{array}{l}\text { Dapat } \\
\text { meningkatkan } \\
\text { komunikasi non } \\
\text { verbal bergerak } \\
\text { mengikuti instruksi, } \\
\text { ekspresi wajah } \\
\text { cerah dan berani } \\
\text { kontak mata }\end{array}$ & $\checkmark$ & $\checkmark$ & $\checkmark$ & $\checkmark$ & $\checkmark$ & $\sqrt{ }$ \\
\hline 3 & $\begin{array}{l}\text { Dapat } \\
\text { meningkatkan } \\
\text { komunikasi verbal } \\
\text { (menyapa Pasien } \\
\text { lain atau perawat) }\end{array}$ & $\checkmark$ & $\checkmark$ & $\checkmark$ & $\checkmark$ & $\checkmark$ & $\sqrt{ }$ \\
\hline 4 & $\begin{array}{l}\text { Dapat } \\
\text { meningkatkan }\end{array}$ & $\sqrt{ }$ & $\checkmark$ & $\checkmark$ & $\checkmark$ & $\checkmark$ & $\sqrt{ }$ \\
\hline
\end{tabular}




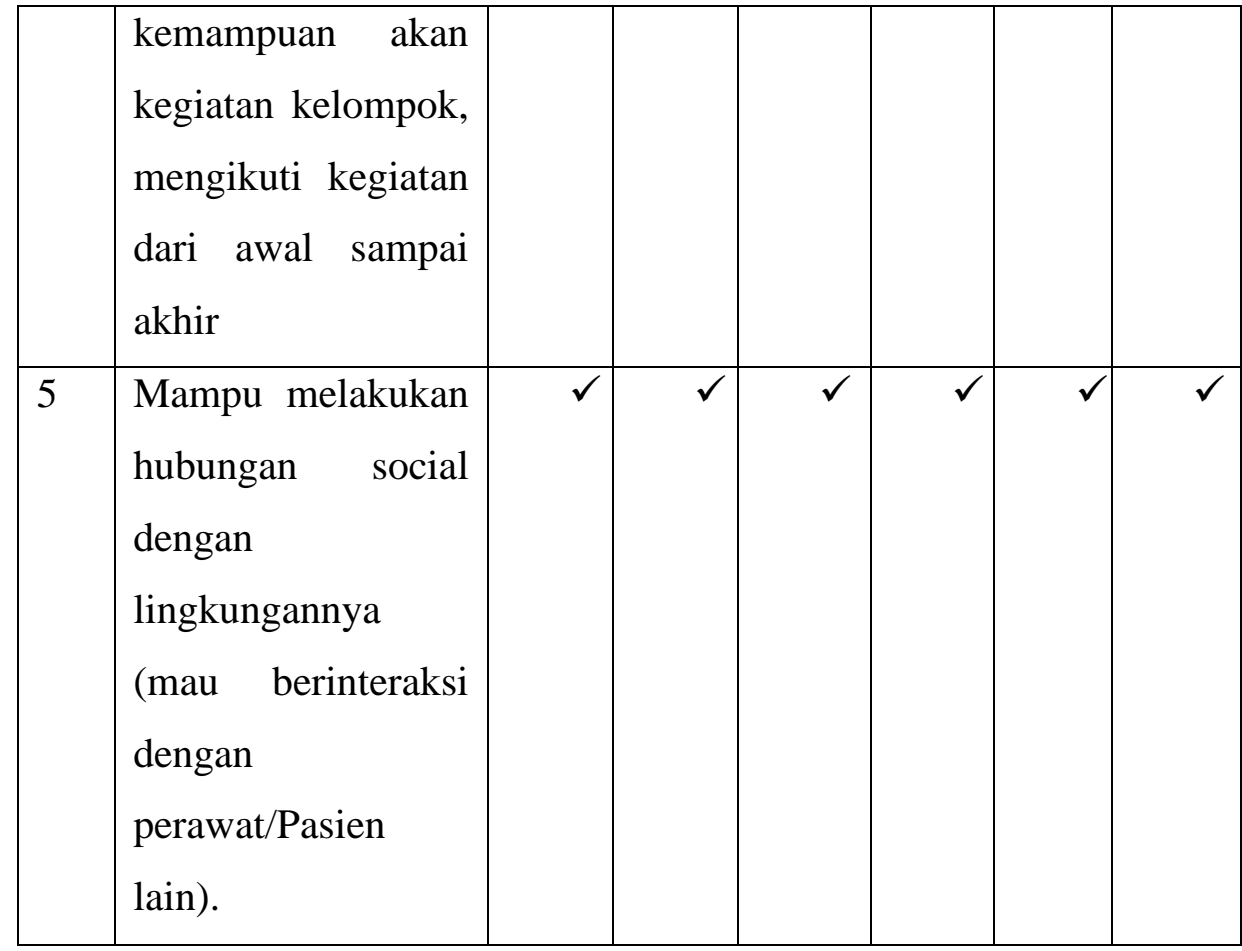

\subsubsection{Kemampuan Verbal : menyampaikan pribadi}

\begin{tabular}{|l|l|r|r|r|r|r|r|}
\hline No & Aspek penilaian & Tn.A & Tn.A & \multicolumn{1}{|c|}{$\begin{array}{c}\text { Ny. } \\
\text { Y }\end{array}$} & Ny.R & Ny.M & \multicolumn{1}{c|}{$\begin{array}{c}\text { Ny. } \\
\text { Y }\end{array}$} \\
\hline 1 & $\begin{array}{l}\text { Menyampaikan } \\
\text { topic dengan jelas }\end{array}$ & X & $\checkmark$ & $\checkmark$ & $\checkmark$ & $\checkmark$ & $\checkmark$ \\
\hline 2 & $\begin{array}{l}\text { Menyampaikan } \\
\text { topic secara } \\
\text { ringkas }\end{array}$ & X & $\checkmark$ & $\checkmark$ & $\checkmark$ & $\checkmark$ & $\checkmark$ \\
\hline 3 & $\begin{array}{l}\text { Menyampaikan } \\
\text { topic yang relevan }\end{array}$ & X & $\checkmark$ & $\checkmark$ & $\checkmark$ & $\checkmark$ & $\checkmark$ \\
\hline 4 & $\begin{array}{l}\text { Menyampaikan } \\
\text { topic secara } \\
\text { spontan }\end{array}$ & X & $\checkmark$ & $\checkmark$ & $\checkmark$ & $\checkmark$ & $\checkmark$ \\
\hline
\end{tabular}

3.1.3 Kemampuan Verbal : memberikan pendapat tetang masalah yang dipaparkan

\begin{tabular}{|c|c|c|c|c|l|l|l|}
\hline No & Aspek penilaian & Tn.A & Tn.A & $\begin{array}{c}\text { Ny. } \\
\text { Y }\end{array}$ & $\begin{array}{l}\text { Ny. } \\
\text { R }\end{array}$ & $\begin{array}{l}\text { Ny. } \\
\text { M }\end{array}$ & $\begin{array}{l}\text { Ny. } \\
\text { Y }\end{array}$ \\
\hline
\end{tabular}




\begin{tabular}{|l|l|r|r|r|r|r|r|}
\hline 1 & $\begin{array}{l}\text { Memberi pendapat } \\
\text { dengan jelas }\end{array}$ & X & $\checkmark$ & $\checkmark$ & $\checkmark$ & $\checkmark$ & $\checkmark$ \\
\hline 2 & $\begin{array}{l}\text { Mampu menebak } \\
\text { ekspresi wajah }\end{array}$ & X & $\checkmark$ & $\checkmark$ & $\checkmark$ & X & $\checkmark$ \\
\hline 3 & $\begin{array}{l}\text { Mampu } \\
\text { menjelaskan } \\
\text { ekspresi wajah }\end{array}$ & X & $\checkmark$ & $\checkmark$ & $\checkmark$ & X & $\checkmark$ \\
\hline 4 & $\begin{array}{l}\text { Mampu SP } \\
\text { menjelaskan Serilaku } \\
\text { resiko } \\
\text { kekerasan }\end{array}$ & $\begin{array}{l}\text { Xampu } \\
\text { memperagakan SP } \\
\text { resiko perilaku } \\
\text { kekerasan }\end{array}$ & $\checkmark$ & $\checkmark$ & X & X & $\checkmark$ \\
\hline 5 & & & & & & \\
\hline
\end{tabular}

\subsubsection{Kemampuan Non Verbal}

\begin{tabular}{|l|l|r|r|r|r|r|r|}
\hline No & \multicolumn{1}{|l|}{ Aspek penilaian } & \multicolumn{1}{c|}{$\begin{array}{l}\text { Tn. } \\
\text { A }\end{array}$} & Tn.A & Ny. y & $\begin{array}{l}\text { Ny. } \\
\text { R }\end{array}$ & $\begin{array}{l}\text { Ny. } \\
\text { M }\end{array}$ & $\begin{array}{l}\text { Ny. } \\
\text { R }\end{array}$ \\
\hline 1 & Kontak Mata & X & $\checkmark$ & $\checkmark$ & $\checkmark$ & $\checkmark$ & $\checkmark$ \\
\hline 2 & Gerakan Tubuh & $\checkmark$ & $\checkmark$ & $\checkmark$ & $\checkmark$ & $\checkmark$ & $\checkmark$ \\
\hline 3 & $\begin{array}{l}\text { Menggunakan } \\
\text { bahasa tubuh yang } \\
\text { sesuai }\end{array}$ & $\checkmark$ & $\checkmark$ & $\checkmark$ & $\checkmark$ & $\checkmark$ & $\checkmark$ \\
\hline 4 & $\begin{array}{l}\text { Mengikuti kegiatan } \\
\text { dari awal sampai } \\
\text { akhir }\end{array}$ & $\checkmark$ & $\checkmark$ & $\checkmark$ & $\checkmark$ & $\checkmark$ & $\checkmark$ \\
\hline
\end{tabular}




\subsection{Respon Pasien}

Respon pasien saat diberikan terapi aktivitas kelompok yaitu :

a. Kemampuan Mengontrol Risiko Perilaku Kekerasan

Pasien mengatakan mampu mengontrol emosi dengan cara tarik nafas dalam dan pukul kasur bantal ketika sedang marah.

b. Kemampuan Patuh Minum Obat

Pasien mengatakan minum obat $2 x /$ hari. Pasien dapat mengatakan keuntungan dengan minum obat yaitu untuk menenangkan pikiran dan pasien bisa tidur dengan nyenyak.

c. Kemampuan Berkomunikasi Secara Verbal

Pasien mengatakan mampu menyelesaikan masalah dengan cara berbicara baik-baik tidak dengan amarah.

d. Kemampuan Spritual

Pasien mengatakan setiap bangun tidur atau melakukan kegiatan selalu diawali dengan doa. Pasien selalu mengikuti kegiatan ibadah di Yayasan pemenang jiwa sumatera. 


\section{BAB 4 \\ PENUTUP}

\subsection{Kesimpulan}

Skizofrenia merupakan gangguan jiwa yang dapat berakhir dengan hilanngya nyawa seseorang. Dalam penanganan penyakit ini karena jiwa yang tergangangu maka di butuhkan adalah terapi, rehabilitasi serta dengan konseling. Upaya terbesar untuk penangan penyakit gangguan jiwa terletak pada keluarga dan masyarakat, dalam hal ini terapi terbaik adalah bentuk dukungan keluarga dalam mencegah kambuhnya penyakit skizofrenia (Pitayanti, \& Hartono, 2020).

Risiko perilaku kekerasan merupakan gejala dari pasien skizofrenia yang dapat dikontrol melalui terapi Aktivitas Kelompok. Terapi aktivitas kelompok stimulasi persepsi merupakan terapi yang diberikan dengan menstimulus semua panca indra pada pasien sehingga terjadi perubahan perilaku dan memberikan respon yang adekuat. Kemampuan persepsi Pasien akan di evaluasi dan ditingkatkan pada tiap sesinya (Arisandy \& Sunarmi, 2018).

Salah satu terapi modalitas yang dapat membantu membangun hubungan pasien dengan orang lain adalah Terapi Aktivitas Kelompok, dengan terapi aktivitas kelompok, pasien dapat bersosialisasi, mengetahui konteks kenyataan, menyalurkan energi, dan meningkatkan harga diri, sehingga pasien dapat mengontrol emosi (Pardede \& Ramadia, 2021).

Setelah mendapatkan terapi aktivitas kelompok stimulasi persepsi, pasien di Yayasan pemenang jiwa sumatera terjadi peningkatan pengetahuan, pemahaman tentang cara mengontrol emosi dan setelah mendapatkan terapi aktivitas kelompok pasien mampu mengingat SP 1-4 dan .tahu bagaimana cara melakukannya. 


\subsection{Saran}

Diharapkan bagi tenaga perawat menjadikan Terapi Aktivitas Kelompok stimulasi persepsi sebagai tindakan keperawatan untuk setiap pasien dengan masalah gangguan jiwa khusunya pasien Risiko Prilaku Kekerasan. Berdasarkan hasil penelitian yang dilakukan oleh Sepalanita \& Khairani (2019), Stimulasi persepsi yang diberikan pada Pasien Risiko Perilaku Kekerasan memberikan pengaruh yang signifikan terhadap kemampuan mengenal dan mengontrol prilaku kekerasan baik secara fisik maupun secara sosial. 


\section{DAFTAR PUSTAKA}

Arisandy, W., \& Sunarmi, S. (2018).Terapi Aktivitas Kelompok Stimulasi Persepsi Berhubungan Dengan Kemampuan Pasien Dalam Mengontrol Perilaku Kekerasan. Jurnal Kebidanan dan Keperawatan Aisyiyah, 14(1), 83-90.https://doi.org/10.31101/jkk.553

Dwijayanti, D. A., Lestari, R. T. R., Lestari, N. K. Y., Wati, N. M. N., \& Masta, I. G. J. (2020). Peningkatan Derajat Kesehatan Mental melalui Terapi Aktivitas Kelompok dalam Posyandu Jiwa. Jurnal Empathy Pengabdian Kepada Masyarakat, 1(1), https://doi.org/10.37341/jurnalempathy.v1i1.3

18-25.

Makhruzah, S., Putri, V. S., \& Yanti, R. D. (2021). Pengaruh Penerapan Strategi Pelaksanaan Perilaku Kekerasan terhadap Tanda Gejala Pasien Skizofrenia di Rumah Sakit Jiwa Daerah Provinsi Jambi. Jurnal Akademika Baiturrahim Jambi, 10(1), 39-46. http://dx.doi.org/10.36565/jab.v10i1.268

Pardede, J. A., \& Ramadia, A. (2021). The Ability to Interact With Schizophrenic Patients through Socialization Group Activity Therapy. International Journal of Health Science and Medical Research, 1(1), 06-10. http://ijhsmr.com/index.php/ijhsmr/article/view/6

Pardede, J. A., Siregar, L. M., \& Hulu, E. P. (2020). Efektivitas Behaviour Therapy Terhadap Risiko Perilaku Kekerasan Pada Pasien Skizofrenia Di Rumah Sakit Jiwa Prof. Dr. Muhammad Ildrem Provsu Medan. Jurnal Mutiara Ners, 3(1), $8-$ 14.http://114.7.97.221/index.php/NERS/article/view/1005

Pardede, J. A., \& Laia, B. (2020). Decreasing Symptoms of Risk of Violent Behavior in Schizophrenia Patients Through Group Activity Therapy. Jurnal Ilmu Keperawatan Jiwa,3(3), 291300.http://journal.ppnijateng.org/index.php/jikj/article/view/621/338

Pitayanti, A., \& Hartono, A. (2020).Sosialisasi Penyakit Skizofrenia Dalam Rangka Mengurangi Stigma Negatif Warga di Desa Tambakmas Kebonsari-Madiun. Journal of Community Engagement in Health, 3(2).https://jceh.org/index.php/JCEH/article/view/83/78

Pratiwi, I. (2020). Gambaran Asuhan Keperawatan Pemberian Terapi Aktivitas Kelompok Stimulasi Persepsi Sesi V: Mencegah Perilaku Kekerasan Dengan Patuh Mengonsumsi Obat Pada Pasien Skizofrenia Tahun 2020 (Doctoral Dissertation, Poltekkes Denpasar Jurusan Keperawatan).Http://Repository.PoltekkesDenpasar.Ac.Id/Id/Eprint/2 $\underline{196}$ 
Riskesdas (2018) Hasil Utama riskesdas 2018 Kementrian Kesehatan Badan Penelitian dan Pengembangan Kesehatan.

Sepalanita, W., \& Khairani, W. (2019). Pengaruh Terapi Aktivitas Kelompok dengan Stimulasi Persepsi terhadap Kemampuan Mengontrol perilaku kekerasan pada Pasien Skizofrenia. Jurnal Ilmiah Universitas Batanghari Jambi, 19(2),

431.http://dx.doi.org/10.33087/jiubj.v19i2.690

Sudiasih, N. N. A. (2020). Gambaran Asuhan Keperawtan Pemberian Terapi Aktivitas Kelompok Stimulasi Persepsi Sensori I: Mengenal Perilaku Kekerasan Untuk Mengatasi Resiko Perilaku Kekerasan Pada Pasien Skizofrenia. Kearya tulis ilmiah, Poltekkes Denpasar Jurusan Keperawatan. http://repository.poltekkes-denpasar.ac.id/id/eprint/4983 